\section{AGAINST GRAND THEORIES: A (CAUTIONARY) TALE OF TWO DISCIPLINES}

\begin{abstract}
In this paper, I combine an exposition of the historical development of sociology and the philosophy of science from the era of grand theories onwards, with an explication as to why the grand theories have failed. First, I trace some parallels in the history of each of the disciplines. After presenting their chronological development, I scrutinize the metatheoretical findings about the disciplines and examine the main ontological and epistemic reasons why attempts at these general theories or frameworks have not succeeded. Among them are the lack of a universal methodology and of a theoretical core, together with the impossibility of achieving a common objective view. On this basis I conclude that general theories or frameworks are not achievable in principle. As it turns out, however, some contemporary social theorists and philosophers still harbor hopes that they can be successfully formulated, or at the least do not rule out such a possibility. Thus, in closing, I argue that the critical points can also be applied to these latest attempts, as the call for grand theories or frameworks has never ceased and returns regularly with each new generation of social theorists and philosophers of science.
\end{abstract}

Keywords: grand theory; metatheory in sociology; metaphilosophy of science; structural functionalism; logical empiricism; relational and analytical sociology

\section{Proti velkým teoriím: (varovný) př́iběh dvou disciplín}

Abstrakt: Tento článek kombinuje prehled historického vývoje sociologie a filosofie vědy od obdobi "velkých" teorií s výkladem toho, proč tyto teorie selhaly. V první části sleduji historické paralely $v$ obou těchto disciplínách. Po představení jejich chronologického vývoje analyzuji metateoretické závěry, které $z$ toho vyplývají, a zkoumám hlavní epistemické a ontologické dìvody, proč neuspěly - mezi nimi chybějící univerzální metodologii a teoretické jádro i nemožnost dosažení objektivního náhledu. Z toho vyvozuji závěr, že velké teorie nejsou principiálně zkonstruovatelné. Ukazuje se nicménè, že někteří současní sociální teoretici i filosofové vědy stále doufají, že takové teorie nebo rámce mohou být úspěšně formulovány, nebo přinejmenším takovou možnost nevylučují. $V$ závěru argumentuji, že kritika vznesená vưči těmto dřivějším teoriím může být uplatněna i na tyto aktuální pokusy. Ukazuje se totiž, že volání po těchto teoriích a rámcích nikdy úplně neprestalo a opakuje se s každou novou generací sociálních vědců a filosofü vědy.

Klíčová slova: velká teorie; metateorie $v$ sociologii; metafilosofie vědy; strukturální funkcionalismus; logický empirismus; relační a analytická sociologie

\section{PETR JEDLIČKA}

Faculty of Arts

University of West Bohemia

Sedláčkova 38, 30100 Plzeň

email / pjedlick@kfi.zcu.cz

(iD 0000-0002-6635-0359

Funded by GA ČR 18-08239S „Objectivity: An Experimental Approach to the Traditional Philosophical Question".

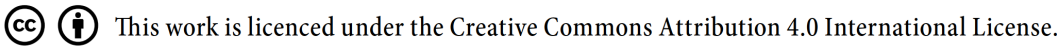


This paper contributes to the ongoing lively debate about a general theory (of any kind) in sociology or the philosophy of science. Although recent attempts, which are mentioned towards the end of this text, are not as audacious as previous ones, such as Parsons's or Vienna and Berlin Circles', they still presume that a general framework can be constructed. For that reason, I not only review the history of these movements, but also present contrary theoretical arguments with the broader aim of dispensing with these continuing calls for holistic frameworks, which appear periodically in both disciplines.

\section{Heyday of the Grand Theories ${ }^{1}$ - Structural Functionalism and Logical Empiricism}

In this first section, I provide an overview of the emergence of grand theoretical systems both in sociology and the philosophy of science and of their fortunes in later decades.

Although the subject matter of the disciplines is different, their history reveals some striking similarities and parallels which still hold up. As sociology and the philosophy of science have often crossed paths in the past, this entanglement also helps to understand their developmental milestones and explain the many blind alleys that they ran into. Comte, who stood at the origin of both sociology and positivist philosophy, can serve as an example of this nexus. But this affiliation does not end here - a rich intellectual exchange has often led to "cross-fertilizing," in which the ideas from one discipline influenced the other. In the next part, I will show that the threads

\footnotetext{
${ }^{1}$ Historically, the term "grand theory" was introduced to sociology by Mills. It denotes the theoretical system put forth by Talcott Parsons and his coworkers and is also occasionally used for other great theoretical systems in sociology. Although not so common in the philosophy of science (or studies of science), the term "grand theory" also refers to a great theoretical system about science, such as "logical empiricism" or similar. Cf. Wright C. Mills, The Sociological Imagination (Oxford: Oxford University Press, 2000); David Hull, "Testing Philosophical Claims about Science," in PSA: Proceedings of the Biennial Meeting of the Philosophy of Science Association 1992: Symposia and Invited Papers, no. 2 (Chicago: University of Chicago Press, 1992), 468-75; Stathis Psillos and Martin Curd, "Introduction," in The Routledge Companion to the Philosophy of Science, eds. Stathis Psillos and Martin Curd (London: Routledge, 2008), $\mathrm{xix}-\mathrm{xxvii}$. Thus, for the purpose of this article, by "grand theory" I mean any general framework that aims to establish an entity (or set of entities), a methodology, or an approach, as a (holistic) principle through which the social world can be understood, described, and explained. By analogy, in the philosophy of science, a grand theory suggests a universal framework (base) for scientific theories, a general explanatory principle, or narrative through which science can be viewed and described.
} 
entwined on more than one occasion, as the disciplines are related on a deep epistemological level.

The late 1920s and 1930s were auspicious times for grand theories which attempted to give birth to a general framework for all-encompassing theories of society, or science, respectively. In the 30 s the possibility of such grandiose undertakings was not disputed, and these programs were carried out largely unquestioned for a number of years. They were usually welcomed and displayed the unmatched self-confidence and optimistic prospects of these disciplines.

A prime specimen of a grand theory was structural functionalism, suggested by Parsons and his coworkers. In their theory of social action and AGIL, their ultimate goal was to create a conceptual scheme that could be universally applied to every current and historical society. What did Parsons's structural functionalism look like? Parsons's forte lays in his synthetic approach which sought to explain all social phenomena within this general framework. For this purpose, he appropriated then-established theories of his predecessors ${ }^{2}$ which he used as building blocks for his new system. Parsons preferred to view society as an integrated whole and he embraced the positivistic doctrine, which, however, needed to be supplemented to include a human aspect. A positivistic bent is especially strong in his The Structure of Social Action, ${ }^{3}$ which aimed to create a coherent "positivistic theory of action." Here, he made extensive use of positivistic language such as "observations of empirical fact," by which he understood any empirically verifiable statement, and stressed the importance of "logical coherence" in the building of theoretical systems. ${ }^{4}$ This overall positivist outlook, however, was coupled with "voluntaristic" aspects in his theory of action - this concession had to be made to include the indispensable human agent, which is necessary for any social theorizing.

Parsons and his collaborators later developed AGIL, a generalized fourfunction conceptual scheme, ${ }^{5}$ which was to be applied across all human societies in history. ${ }^{6}$ In AGIL, he distinguished four problems that each social

\footnotetext{
${ }^{2}$ Although he was also accused of distorting or truncating the classics.

${ }^{3}$ Talcott Parsons, The Structure of Social Action (New York: McGraw Hill, 1937).

${ }^{4}$ Ibid., 41.

${ }^{5}$ Which has, due to its omnipresence in sociological textbooks, become more of a caricature of itself.

${ }^{6}$ Parsons elaborated his AGIL scheme in several works, among the most important are: Talcott Parsons and Edward A. Shils, eds., Toward a General Theory of Action: Theoretical Foundations for the Social Sciences (Cambridge: Harvard University Press, 1951); Talcott
} 
system needs to address, and respective interrelated subsystems which have to perform this function so that the society can survive. These were designated with the four letters A, G, I, and L, where A stands for "adaptation" (the economic subsystem that ensures control over the environment and production), G for "goal attainment" (the political subsystem that is responsible for the collective coordination of social activities), I for "integration" (the normative components such as law and customs that are responsible for societal integration) and L for "pattern maintenance" or "latent function" (the subsystem that serves to reproduce basic principles through acculturation, socialization, and education). In Parsons's view, every society consists of these interrelated functional subsystems that can be further analyzed, and this scheme repeats itself on other levels too: for example, the economic subsystem also consists of four subsystems with the same function (AGIL) and so on. This abstract scheme can be found in all societies in human history and is thus a general theory of society.

Throughout the 50s, Parsons's theory gained immense influence not only in social theory but across neighboring disciplines such as economic sociology, sociology of law and medicine. Parsons also envisioned the integration of sociology around his theory, which was further developed and modified by his students and followers. With its rise and institutional power, structural functionalism became the sociological mainstream, at least in the USA.

Philosophy of science walked along the same path to a large degree. Despite the fact that logical empiricism ${ }^{8}$ is rather a patchwork of approaches than a single unified project, its gist can be briefly summarized: Grounded in empiricism and logicism, logical empiricism should have provided a universal philosophical bedrock for all the sciences, preferably modeled on the most successful natural science of the day - physics. This grand vision

Parsons, The Social System (Glencoe: Free Press, 1951); Talcott Parsons and Neil J. Smelser, Economy and Society: A Study in the Integration of Economic and Social Theory (New York: Routledge, 1956). Later, he presented an even more complicated and generalized system in his human conditions paradigm. See Talcott Parsons, Action Theory and the Human Condition (New York: Free Press, 1978).

${ }^{7}$ The story of logical empiricism and its objectives is quite well known and will not be repeated in full here. For full account, see Ronald N. Giere and Alan W. Richardson, eds., Origins of Logical Empiricism (Minneapolis: University of Minnesota Press, 1996).

${ }^{8}$ I use the term "logical empiricism" in its broad sense as a blanket term for the doctrine or movement which originated in Vienna and Berlin Circles and for their followers. 
also entailed commitments to finding a singular method of inquiry, which, together with verificationism and reductionism, formed its core. ${ }^{9}$

Logical empiricists shared the view that there was a possibility of creating a universal framework resting solely on the firm foundations of empirical experience and logic, which would also do away with the burden of "meaningless" metaphysics. Optimists predicted that logical empiricism would lead to a "unified theory of knowledge," a fully developed base for a future consolidation of the various sciences as to their method, language and structure of their laws. This program was embodied in their cherished project International Encyclopedia of Unified Science ${ }^{10}$ with its goal of elaborating a conceptual synthesis of science, developing a unified scientific language, and working out an appropriate scientific methodology.

\section{The Demise of the Grand Theories and Further Developments}

After their rise to prominence, both structural functionalism of the Parsonian school and logical empiricism of the Vienna and Berlin circles (later transplanted to the USA), began almost simultaneously to lose their ground. Their shared ambition to create "grand theories" to explain society or science in their entirety went unfulfilled, and their programs were dismantled by subsequent generations of sociologists and philosophers of science, which ultimately led to their demise.

While in the 1950s Parsons's hold over the field was enormous, the 1960s painted a different picture for structural functionalism and its influence began to wane. Parsons was criticized for numerous reasons and from diverse perspectives. In 1959, the American sociologist Mills published his highly influential Sociological Imagination ${ }^{11}$ in which he warned againts the "traps of the grand theory": First, the grand theory of Parsons is too general and abstract, to the point that no theorist will ever get down to genuine problems in the social world - the epistemic consequence of which is neither

\footnotetext{
${ }^{9}$ More strands of logical empiricism existed that emphasized various and sometimes incompatible features. Although the authors associated with the movement had common goals, they were not in full agreement about its basic tenets. For example, whereas Carnap professed unification of scientific language and laws, especially in Aufbau, Neurath's position in respect to the unified science seems to be more reserved and he especially eschewed any unification on the basis of a general system which might be in danger of involving metaphysics. Cf. Rudolf Carnap, Der logische Aufbau der Welt (Hamburg: Felix Meiner Verlag, 1961).

${ }^{10}$ Other activities included organizing international congresses, founding of the International Institute for the Unity of Science, or publication of the Journal of Unified Science (Erkentniss). ${ }^{11}$ Wright C. Mills, The Sociological Imagination (Oxford: Oxford University Press, 2000).
} 
better understanding nor increased sensibility. Second, the language and style are outdated. In Mills's view, the grand theory is an "arid game of Concepts," "drunk on syntax, blind to semantics," which "may not be altogether intelligible" due to Parsons's cumbersome writing style. ${ }^{12}$ As to the wider implications of such social science, Mills accused structural functionalism of being in the service of the authorities and thus far from being a valuefree science. He also asserted that the deficiencies of Parsons's works had wider epistemological implications - in stressing normative and integrative structures, Parsons's theories lacked the means to express antagonisms and conflicts in society and were unable to account for social change and historical development. ${ }^{13}$ By the same token, he ascribed problems with the sociological grand theory to the faulty program borrowed from the philosophy of science which attempted to model them on the basis of natural sciences. Mills was not alone in his attack, as similar reservations were expressed by Sorokin, Gouldner, Cole, and many others. "The AGIL typology did not prove to be a very useful descriptive taxonomy, and it is virtually impossible to identify how its development enabled us to understand any particular social phenomenon or outcome," writes Cole in his sweeping rebuttal. ${ }^{14}$

It goes without saying that many of the critical points leveled against structural functionalism held well for logical empiricism too. The movement ${ }^{15}$ found its early vocal critic in Popper, who did not share its views on the scientific method, the role of metaphysics and other crucial issues. ${ }^{16}$ But Popper's major work Logik der Forschung (1935), which provided much ammunition against logical empiricism, did not appear in English translation until 1959 as The Logic of Scientific Discovery ${ }_{1}^{17}$ so its impact was delayed, at

${ }^{12}$ Ibid., 26-34.

${ }^{13}$ Perhaps, not surprisingly, Mills was also pessimistic about science in general when he expressed open dislike for scientism and viewed the modern natural sciences as a highly ambiguous enterprise. Ibid., 16.

${ }^{14}$ Stephen Cole, "Why Sociology Does not Make Progress like the Natural Sciences," Sociological Forum 9, no. 2 (1994): 133-54, 140.

${ }^{15}$ Logical empiricism had its own rich history of fall-outs with philosophical community. The core of the project also ran counter to other strands of continental philosophy, especially Heidegger's metaphysics, to which it directly responded.

${ }^{16}$ Popper's falsificationism is in many points similar to the views of logical empiricists, especially in its reliance on one single principle that guides scientific method, and on those grounds, it can also be included in the family of grand theories of science. For that reason, much of the later criticism was equally valid both for logical empiricism and Popper's falsificationism.

${ }^{17}$ Karl R. Popper, The Logic of Scientific Discovery (London: Hutchinson and Co., 1959). 
least in the English speaking world. In the 1950s and early 1960s, Popper was soon joined by a host of others: Quine, Hanson, Feyerabend, and Kuhn, ${ }^{18}$ all of whom found many weaknesses in the edifice of logical empiricism and helped to undermine its position in the philosophy of science. In the eyes of these authors, logical empiricism was deficient mainly because of its inability to account for scientific dynamics and change. It was blamed for providing only a false, static image of science that cannot account for the representation of scientific development or activity. All in all, the demise of the movement in the philosophical community occurred sometime between the publication of Quine's Two Dogmas of Empiricism ${ }^{19}$ (1951) and Kuhn's Structure (1962), as Friedman asserts. ${ }^{20}$ Especially detrimental for logical empiricism proved to be the publication of Kuhn's oeuvre, the impact of which cannot be overestimated - Kuhn questioned (although did not directly attack) nearly all the basic tenets of logical empiricism. He singlehandedly undercut its prospects for a grand unification theory and showed that the simplifying account of science as a purely rational enterprise had to be supplemented with a new kind of inquiry. Kuhn and his followers put an emphasis on the historical and sociological setting in which any scientific knowledge is produced and broke the ground for an entirely new era. Kuhn decidedly proved that these factors hold epistemological significance and cannot be simply shunted off outside the realm of science as the logical empiricists had attempted.

From this perspective, the criticism of structural functionalism and logical empiricism often converged because they share a similar blind spot - the inability to account fully for the dynamics or conflicts in society or science. As a result, both doctrines came to an impasse and were in their original form discontinued - the structural functionalists suffered substantial neglect in the academic community and publications of the logical empiricists' International Encyclopedia of Unified Science ${ }^{21}$ came to a halt. So, the raison

\footnotetext{
${ }^{18}$ Ironically, Kuhn's Structure was published as a volume of the International Encyclopedia of Unified Science (Volumes I-II: Foundations of the Unity of Science). Rather surprisingly, Carnap and others did not consider it an attack on their project and the Structure has not become a topic for discussion, since they considered it a work in the history of science and not in the philosophy of science. See Thomas S. Kuhn, The Structure of Scientific Revolutions (Chicago: University of Chicago Press, 1962).

${ }^{19}$ William V. O. Quine, "Main Trends in Recent Philosophy: Two Dogmas of Empiricism," The Philosophical Review 60, no. 1 (1951): 20-43.

${ }^{20}$ Michael Friedman, Reconsidering Logical Positivism (Cambridge: Cambridge University Press, 1999), 1.

${ }^{21}$ Kuhn's Structure had only one successor.
} 
d'être for such all-encompassing projects waned, and the disciplines took a different course in general. Both doctrines were soon, in quite graphic language, pronounced dead: "Who now reads Parsons?" asks Bryant ${ }^{22}$ on behalf of sociologists. "Logical positivism, then, is dead, or as dead as a philosophical movement ever becomes," wrote Passmore in his obituary. ${ }^{23}$

At this point, the fate of the two disciplines came into direct contact as the course of events in social sciences was impacted by the turmoil in the philosophy of science and vice versa. Kuhn and his followers drew more attention to the role of social practices in the natural sciences, ${ }^{24}$ but this tide has impacted the social sciences with even greater intensity in return, as they are more vulnerable to all kinds of external factors and pressures. Next, their objectivity was put in question, their status as a science began to erode, and further marginalization in academia as well as lowered trust of the public followed. ${ }^{25}$ Furthermore, this disciplinary conflict did not remain confined to the walls of academia but had a wider societal impact, since the seminal texts (which also became bestsellers) of Mills, Kuhn or Fayerabend appealed to the broader public and these iconoclasts, albeit unintentionally, became the standard-bearers for the 1960s revolt. All in all, the 1960s meant the ultimate death knell for the grand theories.

In spite of the fact that nothing is labelled structural functionalism or logical empiricism anymore,${ }^{26}$ the story does not end there. Looking back, claims of their death seem far-fetched because in the 1980s both doctrines experienced a mild resurrection, and, on top of that, they were partly assimilated into other paradigms and thus remained part of the disciplines' legacy.

In sociology, Parsons's pupils tried to save his kind of theorizing, one example of this being Merton with his proposal of middle-range theories which stand between the macrolevel - the holistic theory of society - and the

${ }^{22}$ Christopher G. A. Bryant, "Review Article: Who Now Reads Parsons?," The Sociological Review 31, no. 2 (1983), 337-49.

${ }^{23}$ John Passmore, "Logical Positivism," in The Encyclopedia of Philosophy, Volume V, ed. Paul Edwards (New York: MacMillan and the Free Press, 1967), 52-57.

${ }^{24}$ Later exacerbated by Feyerabend with his staunch criticism and sometimes vitriolic charges against science itself.

${ }^{25}$ See, e.g., Joseph Lopreato and Timothy Crippen, Crisis in Sociology: The Need for Darwin (New Brunswick: Transaction Publishers, 1999).

${ }^{26}$ Alan Richardson, “That Sort of Everyday Image of Logical Positivism': Thomas Kuhn and the Decline of Logical Empiricist Philosophy of Science," in The Cambridge Companion to Logical Empiricism, eds. Alan Richardson and Thomas Uebel (Cambridge: Cambridge University Press, 2007), 346-70. 
microlevel of empirical research. ${ }^{27}$ And although little development occurred under the rubric of structural functionalism later, Parsonian sociology survived and was absorbed into the works of Alexander (neo-functionalism), Giddens, Barber, Münch and other general theorists, that - according to some voices - even superseded Parsons's work itself. So, Parsons never went away completely and the 1980s saw a reappraisal and restoration of his legacy, mostly based on the merits of his extensive elaboration of many sociologically relevant topics. ${ }^{28}$

In the philosophy of science, logical empiricism never ceased to exist completely and was integrated into various strands of analytical philosophy or the philosophy of science (constructive empiricism, ${ }^{29}$ or naturalism), with which it shared some basic commitments. At the same time its heritage received more favorable treatment by some authors, who valued its worthy features such as logical precision.

Despite this reappraisal, the overall impact and epistemic consequences of this demise were profound. In the 1960s at the latest, it was apparent that the disciplines were unable to find common ground either in methodology or theory. The impossibility of reducing them into a unified basis carried along the message that plurality would be likely to reign in the future.

In sociology, new schools and paradigms strove to secure their spot under the sun: in addition to critical sociology, these included phenomenological sociology, social constructionism, and others that brought new directions and methods, in which subjective perception and everyday reality assumed a privileged spot in the research.

In the philosophy of science, developments led away from logical empiricism in other directions, too - the "new philosophy of science,"30 such as the "sociology of scientific knowledge" or "science and technology

\footnotetext{
${ }^{27}$ A similar tendency for a mesolevel of inquiry was echoed in the history of science as well, for example by Galison, who called for a "mesoscopic" history, located between the universalizing history of scientific instrumentation and a particular history of one scientific artefact. Peter Galison, Image and Logic. A Material Culture of Microphysics (Chicago: University of Chicago Press, 1997), 61-63.

${ }^{28}$ A nuanced view of Parsons, his achievements, and reception of his work can be found in Roland Robertson and Bryan S. Turner, Talcott Parsons: Theorist of Modernity (London: Sage Publications, 1991).

${ }^{29}$ Bas C. van Fraassen, The Scientific Image (Oxford: Clarendon Press, 1980).

${ }^{30}$ Theodore Kisiel and Galen Johnson, "New Philosophies of Science in the USA: A Selective Survey," Zeitschrift für allgemeine Wissenschaftstheorie / Journal for General Philosophy of Science 5, no. 1 (1974): 138-91.
} 
studies," started to gain ground. Walking in Kuhn's footsteps, they stressed discontinuity more than stability and adumbrated brand-new research topics. Philosophers, historians, sociologists and ethnographers of science ${ }^{31}$ set out to study the changes, ruptures, and crises instead of analyzing the logical structure of scientific theories which had been in focus in previous decades.

\section{Incommensurable Disciplines?}

The lesson learned from the collapse of the unification attempts was that various paradigms, schools, or theories were mutually incommensurable and would have to co-exist synchronistically both in sociology and in the philosophy of science. In the late 1960s and early 1970s, the community of practitioners openly or implicitly acknowledged this fact and pluralistic tendencies started to take root in each of the disciplines. This has become more or less the accepted status quo, particularly during the postmodern period in the 1980s and early 1990s - although hegemonistic tendencies never quite ceased to exist, as many battles among various factions fought over the years attest. Yet, the plurality issue was ushered in long before, as I will briefly show in the following paragraphs.

Already in the 1930s, Sorokin, one of the founding fathers of sociology, became a harbinger of the "pluralistic spell," as he aptly observed that the discipline is "overcrowded by a multitude of various and contradictory systems." However, at the same time, he optimistically added that among these theories valid ones can be selected and the rest weeded out - a task that he set for himself. ${ }^{32}$

Also, under later theorists, this kind of sociological metatheorizing flourished. They came up with a number of classifications of sociology, but at the same time often lamented over the state of the discipline. Ritzer, ${ }^{33}$ drawing on Kuhn, offered a tripartite categorization of sociology, where the paradigms of social facts, social definitions, and social behavior competed.

\footnotetext{
${ }^{31}$ Since this period, it would be more appropriate to speak about "studies of science" in general because the boundaries between the philosophy of science and the other above-mentioned fields began to dissolve rapidly from the late $60 \mathrm{~s}$.

${ }^{32}$ Pitirim A. Sorokin, Contemporary Sociological Theories (New York: Harper \& Brothers, 1928), xix. Sorokin himself later updated his original schema in the 1960s.

${ }^{33}$ George Ritzer, "Sociology: A Multiple Paradigm Science," The American Sociologist 10, no. 3 (1975) and George Ritzer, Sociology: A Multiple Paradigm Science (Boston: Allyn and Bacon, 1975).
} 
He also noticed that these paradigms had ambitions to explain social phenomena with a general theory and thus to ascend to hegemony, and that they often spread - along with Kuhn's findings - not based on scientific merits but on the institutional power that their supporters held. At the time of publication, Ritzer was still hopeful that integration was possible, but nothing like that happened. But soon it was quite clear that the old Comtean dream which conceived of sociology as a unified science ("social physics") would never come to fruition, as it could not be successfully based either on a positivistic paradigm nor on any other.

Later a number of others became affiliated with these views: Holmwood and Stewart wrote about a widespread malaise in sociology, especially regarding the prospects of an integrated general theory, which have not yet been developed, and there has been a perception among social theorists that such undertakings were futile and impossible. ${ }^{34}$ Turner saw "a hyperdifferentiation of theories" which were to coexist as their unification was nowhere in sight because sociologists do not agree on what the core problems or epistemology should be. ${ }^{35}$ Also Abbott fully acknowledged this: "The discipline is rather like a caravansary on the Silk Road, filled with all sorts and types of people and beset by bandit gangs of positivists, feminists, interactionists, and Marxists, and even by some larger, far-off states like Economics and the Humanities, all of whom are bent on reducing the place to vassalage." ${ }^{36}$ Last but not least, Levine diagnosed the state of sociology as "muted disquiet," pointing to its fragmentation, the end of grand narratives akin to natural sciences, and weakened disciplinary boundaries. And sociology was not the only field affected. Levine extended his claim to the rest of the social sciences - among them anthropology, psychology, economics, political science, and even history, and juxtaposed it with the optimism that had pervaded these disciplines just a few decades earlier. ${ }^{37}$

The philosophy of science (or the studies of science) has given itself over to this kind of metatheorizing too, when it was apparent after the

\footnotetext{
${ }^{34}$ John Holmwood and Alexander Stewart, "Synthesis and Fragmentation in Social Theory: A Progressive Solution," Sociological Theory 12, no. 1 (1994). Despite their rather dim description of the situation, Holmwood and Stewart still retained some hope for future integration.

${ }^{35}$ Jonathan H. Turner, "Sociological Theory Today," in Handbook of Sociological Theory, ed. Jonathan H. Turner (New York: Springer, 2001).

${ }^{36}$ Andrew D. Abbott, Chaos of Disciplines (Chicago: University of Chicago Press, 2007), 6.

${ }^{37}$ Donald N. Levine, Visions of the Sociological Tradition (Chicago: University of Chicago Press, 1995).
} 
Kuhnian revolt that logical positivism as an "ultimate" theory of science had failed. This question was raised seriously by Lakatos, who, in the early 1970s, broached the topic of multiple theories ("methodologies") of science, when he explicitly admitted that: "There are several methodologies afloat in contemporary philosophy of science" (inductivism, conventionalism, falsificationism, and his own methodology of scientific research programmes). ${ }^{38}$ Here the actual scope of the methodologies or theories of science ${ }^{39}$ was not important, but Lakatos exposed the fact that the discipline was thrown out of kilter by the existence of several rival theories of science which could not be unified under a common banner by the community of philosophers. ${ }^{40}$

Another such admission came from Laudan in the mid-1970s as a part of his attempt to improve Lakatos's proposal..$^{41}$ Laudan, too, acknowledged that there were "numerous rival philosophical accounts" of the scientific methods and theories. Unlike Lakatos's, his metacriterion employed empirical tests against the archetypal cases in the history of science performed by the consensual judgment of the philosophers of science, who were to decide which of the rival methodologies were erroneous based on "pre-analytic intuitions about scientific rationality." ${ }^{32}$ However, Giere found later both these metamethodologies circular and put forth yet another proposal of metacriterion grounded in an evolutionary perspective coupled with cognitive science as a way out. ${ }^{43}$

${ }^{38}$ Imre Lakatos, "The Methodology of Scientific Research Programmes," in Philosophical Papers, Volume I, eds. John Worrall and Gregory Currie (Cambridge: Cambridge University Press, 1978), 103.

${ }^{39}$ Lakatos also interchangeably uses throughout his text the terms "logics of discovery," "systems of appraisal," "theories of scientific rationality," and "definitions of science" for the "systems of rules of the scientific game," as proposed by the different philosophers of science. All of them can be understood "as historiographical (or meta-historical) theories (or research programmes)." Ibid., 102-3.

${ }^{40}$ As is well-known, Lakatos tried to solve the problem by applying his "metacriterion" ("methodology of scientific research programmes of second order") to the existing theories and methodologies of science which sought to maintain the impersonal rationality of the selection process at the same time. Perhaps it is hardly surprising that his own "methodology of scientific research programmes" scored best when tested. Ibid., 132.

${ }^{41}$ Laudan's initial proposal can be found in the fifth chapter of his Progress. See Larry Laudan, Progress and Its Problems: Toward a Theory of Scientific Growth (Berkeley: University of California Press, 1977). Later, he discussed the topic, albeit with a different outcome. See Larry Laudan, "Some Problems Facing Intuitionist Meta-Methodologies Source," Synthese 67, no. 1 (1986).

${ }^{42}$ Laudan, Progress, 160.

${ }^{43}$ Ronald N. Giere, "Philosophy of Science Naturalized," Philosophy of Science 52, no. 3 (1985): $331-56$. 
Therefore, despite these new steps towards unification, the discipline has continued to disintegrate due to strong centrifugal forces and has not displayed any tendency towards a universally accepted solution. It has become apparent that the philosophy of science (or the studies of science) will remain divided and assume a "multiparadigmatic" character. This situation continues up to this day, as the philosophy of science harbors an abundance of schools, paradigms, philosophies, and specialisations with several axes of differentiations. This break-up and disunity were noted by Worrall, who considers the contemporary philosophy of science a "rich and multi-faceted enterprise" in which no single view is possible. ${ }^{44}$ Similarly, Machamer ${ }^{45}$ found it splintered into separate sub-fields such as the philosophy of physics, biology, chemistry, medicine, and economics on the one hand, and science studies on the other - and both of these accompanied by specialized subdisciplines such as practical medical ethics. ${ }^{46}$

The picture in the previous paragraphs may be too brief to capture the subtleties and checkered past of sociology and the philosophy of science, but the simplification notwithstanding, the incommensurability of frameworks truly reflects the persistent problems besetting both disciplines. Longstanding dilemmas and unhealed rifts have resulted in a deep lack of unity that affects the workings of these disciplines, their status in academia and even their perception in the public. At present, neither of the disciplines has a common method or core knowledge with which the majority of their practitioners would identify and approve of. As Seidman describes the situation for sociology: "Unfortunately, theorists have been unable to achieve anything approaching consensus on the core premises, concepts,

\footnotetext{
${ }^{44}$ John Worrall, "Philosophy of Science: Classic Debates, Standard Problems, Future Prospects," in The Blackwell Guide to the Philosophy of Science, eds. Peter K. Machamer and Michael Silberstein (Malden, MA: Blackwell, 2002), 18-36.

${ }^{45}$ Peter Machamer, "A Brief Historical Introduction to the Philosophy of Science," in The Blackwell Guide to the Philosophy of Science, eds. Peter K. Machamer and Michael Silberstein (Malden, MA: Blackwell, 2002).

${ }^{46}$ Also, Radder, for instance, joined the chorus when he pointed to the "increasing specialization" and "fragmentation" with prevailing interdisciplinary approaches and several faultlines as characteristics of the discipline. Cf. Hans Radder, "What Prospects for a General Philosophy of Science?," Journal for General Philosophy of Science / Zeitschrift für allgemeine Wissenschaftstheorie 43, no. 1 (2012), 89-92.
} 
and explanatory models of social knowledge." ${ }^{\text {"47 }}$ A statement that holds for philosophy of science as well.

The absence of a common method or core knowledge means that there is no shared basis on which the disciplines can be built. As a consequence, sociology and the philosophy of science both now live in a state of continuous unrest, in which incommensurable approaches are forced to co-exist. This pluralistic outcome has also put further in question their epistemic standing and significance, which has always been somewhat precarious. How is it possible to rely on them when even the practitioners are not able to reach agreement or produce objective knowledge? Why is it that the disciplines have found themselves in such a trap? And do the social sciences ${ }^{48}$ and philosophy of science and related fields share the same dim predicament?

\section{Why Is It So? Natural and Social Worlds}

When trying to uncover why plurality reigns instead of unity, we can clearly identify some of the multifold ontological and epistemic reasons. Some of them were already spelled out in detail in the classical works of Hayek ${ }^{49}$ and Popper $^{50}$, who addressed the distinction between "physical" and "social" facts, and also warned against blind reliance on positivistic, rationalistic or naturalistic methodologies in the studies of society or science. Neither discipline in particular should neglect the unpredictability of the "human factor" or the "growth of human knowledge," they cautioned. ${ }^{51}$

Many of these points can be illuminated by the distinctions between exact sciences that study natural phenomena and "soft" sciences that study phenomena with any social component. Although these distinctions cannot be dissected in detail here, we can determine several features that are sali-

\footnotetext{
${ }^{47}$ Steven Seidman, Contested Knowledge: Social Theory Today (Chichester: John Wiley \& Sons, 2013), 2.

${ }^{48}$ We can extend our analysis to the social sciences in general since the following points concern all social sciences.

${ }^{49}$ Friedrich Hayek, The Counter-Revolution of Science: Studies on the Abuse of Reason (Glencoe: Free Press, 1952).

${ }^{50}$ Karl R. Popper, Poverty of Historicism (London: Routledge, 1957).

${ }^{51}$ Later, authors such as Cole et al., addressed the issue of why sociology is not as successful qua science, cf. Stephen Cole, ed., What's Wrong with Sociology? (New Brunswick: Transaction Publishers, 2001). Especially, Cole's "Introduction" and first chapter "Why Sociology Doesn't Make Progress like the Natural Sciences." Cole names as one of the reasons the difficulty of "establish[ing] facts" in sociological research compared to any natural science (especially if they run contrary to some particular ideological beliefs held by sociologists).
} 
ent for the relative success of the natural sciences as compared to the social sciences:

1. Unlike the natural world, the social world is much more complex whereas a natural phenomenon can be described by a handful of universal laws, a social phenomenon resists such an easy description.

2. Add a lack of controlled experiments - in the natural sciences, the researcher usually works in controlled laboratory conditions, whereas in the social sciences such full control of the research object is much more difficult to obtain, or excluded altogether for various reasons.

3. At least some social phenomena tend to have multiple causes, so in social sciences establishing causal-links can be challenging.

4. The transience of social phenomena causes their high mutability across time and space.

5. One of the peculiarities of the investigation of human and social behavior is the notorious interplay between reality and its theoretical description. Merton's "self-fulfilling prophecy," "reflexivity" in sociology or "performativity" in economics reveal that fully independent analysis in these disciplines is almost impossible to achieve.

6. Related to this is the "observer effect" which usually prevents the researcher from studying social phenomena "objectively" without affecting them..$^{52}$

7. Last but not least, the social sciences are never value-free and are always prone to intervention from "external influences" of any kind, which removes them even further from the ideal of objective science and makes any consensus among social scientists difficult to obtain.

Likewise, the philosophy of science (and all the disciplines studying science) face similar problems. Both formalized theories of science of the positivistic bent and empirical theories of scientific evolution or development find themselves in the same predicament as the social sciences. The phenomena under study are so complex that formulations of any (logical or empirical) "laws" are notoriously difficult. Aside from all the reasons cited above, "serendipidity" is a prominent factor which makes the search for any discernible patterns in scientific activities quite challenging. This is why all

\footnotetext{
${ }^{52}$ The "observer effect" is, of course, not restricted to social sciences, but its presence in microphysics does not prevent physics from formulating exact theories at least on the level of macroobjects.
} 
the ambitious projects - be it the grand vision of logical empiricists, later theories of scientific change, or cognitive models of science ${ }^{53}$ - have not lived up to their promise as unifying frameworks.

All these basic ontological and epistemological obstacles prevent the disciplines that study highly complex phenomena such as societ ${ }^{54}$ or science from becoming as successful as the natural sciences. The acknowledgement of this simple fact and its implications should be the point of departure for every social scientist or philosopher of science. But this is not the case, as we will see.

\section{The Eternal Dreaming of a Grand Theory}

I believe my account has sufficiently established that creating an overarching, universally shared framework or theory for complex phenomena such as society or science is impossible. Given this, it is therefore surprising that a number of social scientists or philosophers of science still keep trying to advance their own versions of grand theories, frameworks, or narratives (or at least plans thereof).

Already in the mid-1980s Skinner ${ }^{55}$ argued that in many fields grand theories had been making a comeback, after they had almost disappeared from the scene. He pointed out that Mills, Kuhn and the likes only cleared the way for new grand theories (sometimes in disguise) that came to occupy their place. And there seems to be a certain justification to this claim. A candidate to fill the void seemed to be the Giddens' structuration theory, ${ }^{56}$ and

${ }^{53}$ Cf., e.g., Ronald N. Giere, "Introduction," in Cognitive Models of Science, Minnesota Studies in Philosophy of Science, ed. Ronald N. Giere (Minneapolis: University of Minnesota Press, 1992), xv-xxviii.

${ }^{54}$ Clearly, the points that I made earlier are not restricted to sociology. Economics, for example, is considered the most exact social science, but it is beset by the same problems arising from the complexity of social reality. Here, typically, simple laws can be formulated, such as supply-demand theory, which are seemingly immutable. However, they also hold only under ceteris paribus conditions when other variables are stable. But this is seldom the case in any society, because social, political, ideological, psychological, or other variables intervene. Thus, ceteris paribus as the condition sine qua non for economic theories, reveals the simplifications of a complex reality. In the popular discourse, which nevertheless has a strong theoretical underpinning, this is acknowledged in "black swan" theories, which show clearly that economic subsystem cannot be separated from other outer events.

${ }^{55}$ Quentin Skinner, "Introduction," in The Return of Grand Theory in the Human Sciences (Cambridge: Cambridge University Press, 1985), 1-20.

${ }^{56}$ Anthony Giddens, The Constitution of Society. Outline of the Theory of Structuration. (Oxford: Polity Press, 1984). 
his successors Archer and Mouzelis, ${ }^{57}$ but there were also other pretenders such as Habermas, Bourdieu, or Alexander, ${ }^{58}$ who sought to reconcile the existing rifts and provide a general theory of a sort. Theoreticians such as Turner and Boyn $\mathrm{s}^{59}$ maintain that "the micro-meso-macro linkage problem" is the main obstacle standing in the way to the desirable return of a grand theory, and in overcoming it they see a way ahead that should prevent both the overspecialization and the decline of the status of sociology. ${ }^{60}$

Among these attempts, we can also count some more recent trends relational or analytical sociology. Though more sober, and aware of the fate of the previous grand theories, some of these contemporary theorists still aspire to exactly the kind of unification that was promised by previous grand theorists. Relational sociolog $y^{61}$ shifts the attention to the dynamic and processual side in the description of social reality with a view toward reworking the existing key sociological general concepts on all levels (macro-, meso-, micro) from the relational viewpoint. To support this extensive claim, Vandenberghe speaks about "a single framework" that would "systematically integrate the concepts of the field" into a "general relational social theory." ${ }^{2}$ On a related note, analytical sociology has been trying to establish social mechanisms ("social cogs and wheels") as universal axioms through which social facts should be explained (Hedström, Manzo, etc.). ${ }^{63}$ But these attempts patently face the same obstacles as all the previous ones

${ }^{57}$ Margaret Archer, Realist Social Theory: The Morphogenetic Approach (Cambridge: Cambridge University Press, 1995); Nicos Mouzelis, Sociological Theory: What Went Wrong? Diagnosis and Remedies (London: Routledge, 1995).

${ }^{58}$ Axel Van den Berg, "Is Sociological Theory Too Grand for Social Mechanisms?," in Social Mechanisms: An Analytical Approach to Social Theory, eds. Peter Hedström and Richard Swedberg (New York: Cambridge University Press, 1998).

${ }^{59}$ Jonathan H. Turner and David E. Boyns, "The Return of Grand Theory," in Handbook of Sociological Theory, ed. Jonathan H. Turner (New York: Springer, 2001).

${ }^{60}$ Other such proposal was Ritzer's call for an "integrated paradigm," which sought to reconcile the micro and the macro level theories. See George Ritzer, Explorations in Social Theory: From Metatheorizing to Rationalization (London: Sage Publications, 2001).

${ }^{61}$ Cf. Mustafa Emirbayer, "Manifesto for a Relational Sociology," The American Journal of Sociology 103, no. 2 (1997); François Dépelteau, ed., The Palgrave Handbook of Relational Sociology (Cham: Springer, 2018).

${ }^{62}$ Frédéric Vandenberghe, "The Relation as Magical Operator: Overcoming the Divide Between Relational and Processual Sociology," in The Palgrave Handbook of Relational Sociology, ed. François Dépelteau (Cham: Springer, 2018), 37.

${ }^{63}$ Cf. Peter Hedström and Peter Bearman, eds., The Oxford Handbook of Analytical Sociology (Oxford: Oxford University Press, 2011), 1-17; Gianluca Manzo, ed., Analytical Sociology: Actions and Networks (Chichester: John Wiley \& Sons, 2014). 
- they just select one mode of description and explanation over another, and there is hardly a chance that they would be promoted into a standard general framework or social theory that would be commonly agreed upon.

In the philosophy of science, the developments of the 1960s also only superficially dispensed with grand theories. Following sociology, Kuhn's paradigms - as well as Lakatos's research programmes, Laudan's research traditions, Toulmin's evolutionary epistemolog $y^{64}$ and other theories - successfully filled the void left by logical empiricism and enriched the discipline with accounts of scientific change that did justice to its dynamics and contingent nature. However, these new theories construed their own holistic and universal frameworks which came with shortcomings not dissimilar to the ones found in older theories.

Later, in the $21^{\text {st }}$ century philosophy of science, the call to arms has not ceased either. Psillos, ${ }^{65}$ despite his acknowledgement of "the collapse of the macro-models of science," brings back to life the essentialist claims about the existence of a "science in general" which should lend itself to analysis by a general philosophy of science. Further, in his programmatic piece, Psillos also attempts to defy the disintegration tendencies in the philosophy of science in the past decades and wants to create "a new synthesis within general philosophy of science" that would encompass its constitutive and historical elements.

A more extensive attempt was undertaken by Barseghyan. ${ }^{66}$ Again, Barseghyan is aware of the atomized state of the discipline, in which there is no consensus as to the characteristics of a general theory or the criteria that it should satisfy, but is nevertheless committed to overcoming these odds. ${ }^{67} \mathrm{He}$ thinks that the development of science is a law governed process, which leads him to the conclusion that "a general descriptive theory of

${ }^{64}$ Stephen Toulmin, Human Understanding (Oxford: Clarendon Press, 1972).

${ }^{65}$ Psillos again argues in favor of a general theory of science. His text is conceived as a reply to Kitcher, who is equally skeptical about the possibility of a general theory on similar grounds as those presented in my article. See Stathis Psillos, "What is General Philosophy of Science?," Journal for General Philosophy of Science / Zeitschrift für allgemeine Wissenschaftstheorie 43, no. 1 (2012): 93-103; Stathis Psillos, "Having Science in View: General Philosophy of Science and its Significance," in Oxford Handbook of the Philosophy of Science, ed. Paul Humphreys (Oxford: Oxford University Press, 2016). Cf. Philip Kitcher, "Toward a Pragmatist Philosophy of Science," Theoria 77 (2013): 185-231.

${ }^{66}$ Barseghyan dubbed the new venture a "scientonomy," which he considers to be "an academic discipline" with "two major branches - theoretical scientonomy and observational scientonomy." As of 2019, the scientonomic community already has its own journal (Scientonomy), encyclopedia, seminars, and conferences, etc.

${ }^{67}$ Hakob Barseghyan, The Laws of Scientific Change (Cham: Springer, 2015), xiv. 
scientific change (TSC)" is not only "theoretically possible" but also "practically achievable." 68 Thus, his work aims at exactly that - establishing the foundations that would explain the mechanisms of scientific change both in theories and methods ${ }^{69}$ His theory is built in an axiomatic fashion, with "axioms," "theorems," and "laws" comprising the body of the theory which is accompanied by a metatheoretical warrant. All these and other attempts ${ }^{70}$ are necessarily exposed to the same critical arguments that have been raised before.

Apparently, neither current social scientists nor philosophers of science seem immune to the lure of grand theorizing (or narrativizing), and they still assume that some sort of a general doctrine or framework can be constructed.

Perhaps the main lesson to be learned from the disciplines' history is not that these frameworks cannot be created, or that they would be wrong, but that they can be supplied in unlimited numbers - as society and science can be modeled in myriads of ways.

Of course, there is still a theoretical possibility of such frameworks, but it would not be, in my opinion, based on current theories or a combination thereof, as none of them seems to be equipped to serve this purpose.

But why is it then that practitioners still harbor such hopes and keep churning out their theories, or at least proposals for them? Abbott ${ }^{71}$ offers an interesting sociological explanation, which is dialectical (Hegelian) in nature. ${ }^{72}$ According to him, the reason is the natural dynamics of sociology, in which every new generation must inevitably compete for attention, recognition, and resources with the "old guard." To prove itself in the academic world the new generation has to uproot the old idols, and erect their own deities instead, as a part of normal generational exchange. ${ }^{73}$ This cyclical de-

\footnotetext{
${ }^{68}$ Ibid., xiii.

${ }^{69}$ Ibid., xiv.

${ }^{70}$ There are more examples like this, e.g., Luk's proposal for a "process model of scientific study" or a "theory of scientific study." Cf. Robert W. P. Luk, "Understanding Scientific Study via Process Modeling," Foundations of Science 15, no. 1 (2010): 49-78; and Robert W. P. Luk, "A Theory of Scientific Study," Foundations of Science 22, no. 1 (2017): 11-38.

${ }^{71}$ Abbott, Chaos, xvi.

${ }^{72}$ Another comprehensive treatment of the rules of intellectual life is presented in Randall Collins, The Sociology of Philosophies: A Global Theory of Intellectual Change (Cambridge: Belknap Press, 2000).

${ }^{73}$ Abbott illustrates this process using Parsons (thesis) and his successors (anthithesis). Another example is a constant revamping of the idea of "social constructivism." Ibid., 17-18. By the way, it is also worth noting that some of the features of Abbott's theory (such as selfsimilarity) closely resemble Parsons's own ideas (subsystems).
} 
velopment is - as Abbott somehow cynically reflects - often accompanied by fierce struggles between newcomers and orthodoxy in academic structures.

But during this process (which concerns not only theories but also methods), even novices often do no more than rediscover the wheel, for they merely "recontextualize" old ideas and bring them back under new names, and this fact further undermines the credibility and standing of the disciplines. Besides sociology proper, Abbott extended his claim to the sociology of science as well, where the tradition of putting "old wine in new bottles" also took root. ${ }^{74}$

We can see Abbott's ideas at work, for example, in social theory in which the fortunes of "agency" and "structure" perpetually shift, or in current analytical sociology which successfully rehashes the strategies of the mechanistic and biological schools in sociology by borrowing concepts and models from other sciences.

\section{Acknowledgements:}

I thank the anonymous reviewers for their insightful comments and suggestions.

\section{Bibliography:}

Abbott, Andrew D. Chaos of Disciplines. Chicago: University of Chicago Press, 2007.

Archer, Margaret. Realist Social Theory: The Morphogenetic Approach. Cambridge: Cambridge University Press, 1995. https://doi.org/10.1017/CBO9780511557675.

Barseghyan, Hakob. The Laws of Scientific Change. Cham: Springer, 2015. https://doi.org/10.1007/978-3-319-17596-6.

Benthem, Johan van. “The Logic of Empirical Theories Revisited." Synthese 186, no. 3 (2012): 775-92. https://doi.org/10.1007/s11229-011-9916-6.

Berg, Axel van den. "Is Sociological Theory Too Grand for Social Mechanisms?" In Social Mechanisms: An Analytical Approach to Social Theory, edited by Peter Hedström and Richard Swedberg, 204-37. New York: Cambridge University Press, 1998. https://doi.org/10.1017/CBO9780511663901.009.

${ }^{74}$ Ibid., 78. 
Bryant, Christopher G. A. "Review Article: Who Now Reads Parsons?" The Sociological Review 31, no. 2 (1983): 337-49.

Carnap, Rudolf. Der logische Aufbau der Welt. Hamburg: Felix Meiner Verlag, 1961.

Cole, Stephen, ed. What's Wrong with Sociology? New Brunswick: Transaction Publishers, 2001.

Cole, Stephen. "Why Sociology Doesn't Make Progress like the Natural Sciences." Sociological Forum 9, no. 2 (1994): 133-54.

Collins, Randall. The Sociology of Philosophies: A Global Theory of Intellectual Change. Cambridge, MA: Belknap Press, 2000.

Dépelteau, François, ed. The Palgrave Handbook of Relational Sociology. Cham: Springer, 2018.

Emirbayer, Mustafa. "Manifesto for a Relational Sociology." The American Journal of Sociology 103, no. 2 (1997): 281-317. https://doi.org/10.1086/231209.

Fraassen, Bas C. van. The Scientific Image. Oxford: Clarendon Press, 1980. https://doi.org/10.1093/0198244274.001.0001.

Friedman, Michael. Reconsidering Logical Positivism. Cambridge: Cambridge University Press, 1999.

Galison, Peter. Image and Logic. A Material Culture of Microphysics. Chicago: University of Chicago Press, 1997.

Giddens, Anthony. The Constitution of Society. Outline of the Theory of Structuration. Oxford: Polity Press, 1984.

Giere, Ronald N. "Philosophy of Science Naturalized." Philosophy of Science 52, no. 3 (1985): 331-56. https://doi.org/10.1086/289255.

Giere, Ronald N. "Introduction." In Cognitive Models of Science, Minnesota Studies in Philosophy of Science, vol. XV, edited by Ronald N. Giere, xv-xxviii. Minneapolis: University of Minnesota Press, 1992.

Giere, Ronald N., and Alan W. Richardson, eds. Origins of Logical Empiricism. Minneapolis: University of Minnesota Press, 1996.

Hayek, Friedrich. The Counter-Revolution of Science: Studies on the Abuse of Reason. Glencoe: Free Press, 1952. 
Hedström, Peter, and Peter Bearman, eds. The Oxford Handbook of Analytical Sociology. Oxford: Oxford University Press, 2011.

Holmwood, John, and Alexander Stewart. "Synthesis and Fragmentation in Social Theory: A Progressive Solution.” Sociological Theory 12, no. 1 (1994): 83-100. https://doi.org/10.2307/202037.

Hull, David. “Testing Philosophical Claims about Science." In PSA: Proceedings of the Biennial Meeting of the Philosophy of Science Association 1992: Symposia and Invited Papers, no. 2. Chicago: University of Chicago Press, 1992. https://doi.org/10.1086/psaprocbienmeetp.1992.2.192859.

Kisiel, Theodore, and Galen Johnson. "New Philosophies of Science in the USA: A Selective Survey." Zeitschrift für allgemeine Wissenschaftstheorie/Journal for General Philosophy of Science 5, no. 1 (1974): 138-91. https://doi.org/10.1007/BF01809877.

Kitcher, Philip. “Toward a Pragmatist Philosophy of Science.” Theoria 77 (2013): 185-231. https://doi.org/10.1387/theoria.7014.

Kuhn, Thomas S. The Structure of Scientific Revolutions. Chicago: University of Chicago Press, 1962.

Lakatos, Imre. “The Methodology of Scientific Research Programmes.” In Philosophical Papers By Imre Lakatos, Volume I, edidted by John Worrall and Gregory Currie. Cambridge: Cambridge University Press, 1978.

Laudan, Larry. Progress and Its Problems: Toward a Theory of Scientific Growth. Berkeley: University of California Press, 1977.

Laudan, Larry. "Some Problems Facing Intuitionist Meta-Methodologies Source." Synthese 67, no. 1 (1986): 115-29.

Levine, Donald N. Visions of the Sociological Tradition. Chicago: University of Chicago Press, 1995.

Lopreato, Joseph, and Timothy Crippen. Crisis in Sociology: The Need for Darwin. New Brunswick: Transaction Publishers, 1999.

Luk, Robert W. P. "Understanding Scientific Study via Process Modeling." Foundations of Science 15, no. 1 (2010): 49-78. https://doi.org/10.1007/s10699-009-9168-9.

Luk, Robert W. P. "A Theory of Scientific Study.” Foundations of Science 22, no. 1 (2017): 11-38. https://doi.org/10.1007/s10699-015-9435-x. 
Machamer, Peter. "A Brief Historical Introduction to the Philosophy of Science." In The Blackwell Guide to the Philosophy of Science, edited by Peter K. Machamer and Michael Silberstein, 1-17. Malden, MA: Blackwell, 2002.

https://doi.org/10.1002/9780470756614.ch1.

Manzo, Gianluca, ed. Analytical Sociology: Actions and Networks. Chichester: John Wiley \& Sons, 2014. https://doi.org/10.1002/9781118762707.

Mills, Wright C. The Sociological Imagination. Oxford: Oxford University Press, 2000.

Mouzelis, Nicos. Sociological Theory: What Went Wrong? Diagnosis and Remedies. London: Routledge, 1995.

Parsons, Talcott, and Edward A. Shils, eds. Toward a General Theory of Action: Theoretical Foundations for the Social Sciences. Cambridge: Harvard University Press, 1951.

Parsons, Talcott, and Neil J. Smelser. Economy and Society: A Study in the Integration of Economic and Social Theory. New York: Routledge, 1956.

Parsons, Talcott. The Structure of Social Action. New York: McGraw Hill, 1937.

Parsons, Talcott. The Social System. Glencoe: Free Press, 1951.

Parsons, Talcott. Action Theory and the Human Condition. New York: Free Press, 1978.

Passmore, John. "Logical Positivism.” In The Encyclopedia of Philosophy, vol. V, edited by Paul Edwards, 52-57. New York: MacMillan and the Free Press, 1967.

Popper, Karl R. The Logic of Scientific Discovery. London: Hutchinson and Co., 1959.

Popper, Karl R. Poverty of Historicism. London: Routledge, 1957.

Psillos, Stathis. "What is General Philosophy of Science?" Journal for General Philosophy of Science / Zeitschrift für allgemeine Wissenschaftstheorie 43, no. 1 (2012): 93-103. https://doi.org/10.1007/s10838-012-9182-4.

Psillos, Stathis. "Having Science in View: General Philosophy of Science and its Significance." In Oxford Handbook of the Philosophy of Science, edited by Paul Humphreys, 137-62. Oxford: Oxford University Press, 2016. https://doi.org/10.1093/oxfordhb/9780199368815.013.7. 
Psillos, Stathis, and Martin Curd. "Introduction." In The Routledge Companion to the Philosophy of Science, edited by Stathis Psillos and Martin Curd, xix-xxvii. London: Routledge, 2008.

Quine, William V. O. "Main Trends in Recent Philosophy: Two Dogmas of Empiricism.” The Philosophical Review 60, no. 1 (1951): 20-43. https://doi.org/10.2307/2181906.

Radder, Hans. "What Prospects for a General Philosophy of Science?" Journal for General Philosophy of Science / Zeitschrift für allgemeine Wissenschaftstheorie 43, no. 1 (2012): 89-92. https://doi.org/10.1007/s10838-012-9180-6.

Richardson, Alan. "That Sort of Everyday Image of Logical Positivism: Thomas Kuhn and the Decline of Logical Empiricist Philosophy of Science." In The Cambridge Companion to Logical Empiricism, edited by Alan Richardson and Thomas Uebel, 346-70. Cambridge: Cambridge University Press, 2007.

Ritzer, George. "Sociology: A Multiple Paradigm Science." The American Sociologist 10, no. 3 (1975): 156-67.

Ritzer, George. Explorations in Social Theory: From Metatheorizing to Rationalization. London: Sage Publications, 2001.

Robertson, Roland, and Bryan S. Turner. Talcott Parsons: Theorist of Modernity. London: Sage Publications, 1991.

Seidman, Steven. Contested Knowledge: Social Theory Today. Chichester: John Wiley \& Sons, 2013.

Skinner, Quentin. "Introduction." In The Return of Grand Theory in the Human Sciences, ed. Quentin Skinner, 1-20. Cambridge: Cambridge University Press, 1985. Sorokin, Pitirim A. Contemporary Sociological Theories. New York: Harper, 1928.

Toulmin, Stephen. Human Understanding. Oxford: Clarendon Press, 1972.

Turner, Jonathan H. “Sociological Theory Today.” In Handbook of Sociological Theory, ed. Jonathan H. Turner, 1-17. New York: Springer, 2001.

Turner, Jonathan H., and David E. Boyns. “The Return of Grand Theory.” In Handbook of Sociological Theory, edited by Jonathan H. Turner, 353-78. New York: Springer, 2001.

Vandenberghe, Frédéric. "The Relation as Magical Operator: Overcoming the Divide Between Relational and Processual Sociology." In The Palgrave Handbook 
of Relational Sociology, edited by Francois Dépelteau, 35-57. Cham: Springer, 2018. https://doi.org/10.1007/978-3-319-66005-9_2.

Worrall, John. "Philosophy of Science: Classic Debates, Standard Problems, Future Prospects." In The Blackwell Guide to the Philosophy of Science, edited by Peter K. Machamer and Michael Silberstein, 18-36. Malden, MA: Blackwell, 2002. 